\title{
PENGEMBANGAN USAHA TERHADAP PEREMPUAN BALI PASCA PERCERAIAN DARI PERKAWINAN CAMPURAN BERMUATAN GENDER

\author{
DALAM HUKUM
}

\author{
Ni Ketut Sari Adnyani \\ Program studi Fakultas Hukum Universitas Ganesha Singaraja \\ Jl. Udayana No. 11 Singaraja Bali 22570 \\ (niktsariadnyani@gmail.com)
}

\begin{abstract}
Abstrak,
Penelitian ini bertujuan untuk mengkaji peluang atau kesempatan bagi perempuan Bali dalam bidang pengembangan usaha pasca perceraian dari perkawinan campuran, mengedepankan prinsip responsive gender ke dalam awig-awig, ilmplikasi muatan toleransi menyama braya, status krama istri, serta menjalankan kewajiban ngayah pada saat piodalan di pura Tri Kahyangan menjadi tujuan dari muatan gender dalam hukum terhadap usaha yang dikembangkan. Metode penelitian dalam penelitian ini adalah sociological jurisprudence, dan jenis penelitiannya adalah studi analitik terhadap bahan hukum yang mengadopsi hak-hak perempuan di bidang dunia usaha. Bahan Hukum yang mengikat tertap mengacu pada UUD Negara Republik Indonesia Pasal 18 B ayat (2) dan Awig-Awig Desa Adat yang mengacu pada Keputusan Nomor 01/KEP/PSM3?MDP/Bali/X/2010 oleh Majelis Utama Desa Pakraman (MUDP) Bali tentang unsur pembagian waris perempuan Bali berstatus (pradana) berhak memperoleh warisan meskipun sudah kawin dan mengikuti suaminya, warisan berupa harta tetadan dapat menjadi modal utama untuk pengembangan usaha dalam konteks hukum bisnis. Penentukan subjek penelitian dilakukan secara stratified random sampling. Teknik Analisa bahan hukum yaitu deskriptif. Hasil penelitian: perempuan Bali diberikan kesempatan diterima menjadi krama istri berdasarkan kesepakata pra perkawinan dari pihak mempelai, keluarga mempelai, dan desa adat yang memuat ketentuan bahwa di kemudian hari apabila terjadi peristiwa perceraian adat siap menerima dan memberikan peluang untuk menjalankan rutinitas seperti krama istri umumnya. Implikasi dari muatan gender dalam hukum bahwa merujuk consensus dari hasil musyawarah desa adat perempuan yang menyamdang status janda dari perkawinan campuran diberikan kesempatan membuka peluang usaha di wilayah desa setempat, dan berhak memperoleh hibah warisan sesuai dengan ketentuan yang diadopsi dari MUDP Bali setelah memperoleh kesepakatan dengan keluarga besar melalui rembug keluarga dengan pihak desa adat (Dharma Pula).
\end{abstract}

Kata kunci : gender, hukum, perempuan, usaha.

\section{Abstract,}

This study aims to examine the opportunities for Balinese women in the field of business development after divorce from mixed marriages, prioritizing the principle of gender responsiveness into awig-awig, the application of the burden of tolerance to 
menyama braya, the status of krama istri, and carrying out the obligation to dance at the temple. Tri Kahyangan is the goal of the gender content in the law of the business being developed. The research method in this study is sociological jurisprudence, and the type of research is analytic study of legal materials that adopt women's rights in the business world. The binding legal material refers to the Republic of Indonesia State Constitution Article 18 B paragraph (2) and the Traditional Village Awigers which refer to the Decree Number 01 / KEP / PSM-3/ MDP / Bali / X / 2010 by the Main Assembly of the Pakraman Village ( MUDP) Bali concerning the division of inheritance of Balinese women with status (pradana) has the right to inherit even though they have married and followed her husband, inheritance in the form of assets can be the main capital for business development in the context of business law. The determination of the research subject was carried out by stratified random sampling. Legal material analysis techniques are descriptive. The results of the study: Balinese women were given the opportunity to be accepted as wife's manners based on the pre-marital agreement of the bride, bride's family, and traditional village which contained the provision that in the future if an incident of custom divorce is ready to accept and provide opportunities to carry out routines such as the wives of their wives in general. The implication of the gender content in the law is that the consensus reference from the results of the women's traditional village meeting that is the status of widows from mixed marriages is given the opportunity to open business opportunities in the local village area, and is entitled to inheritance grants in accordance with the provisions adopted by MUDP Bali after obtaining an agreement with the family big through family consultation with the traditional village (dharma pula).

Keywords: gender, law, women, business

\section{PENDAHULUAN}

Pengarusutamaan gender dalam pembangunan menyelaraskan dengan hubungan hukum terjadi karena peningkatan peningkatan warga negara asing yang berkunjung dan sebagai tenaga kerja di Bali sejumlah $\pm 60 \%$ (NusaBali.com, 17 April 2018). Selama ini belum ada pengaturan mengenai perlindungan perempuan dari desa adat bilamana perempuan Bali bercerai dari status perkawinan campuran. Sudiana (2012) meneliti mengenai upaya-upaya mengimplementasikan konvensi wanita dalam awig-awig. Winarna (2017) lebih menekankan pada analisa terhadap hak pakai atas rumah hunian warga negara asing dalam perkawinan campuran tanpa perjanjian kawin. Temuan masalah berdasarkan kasus perceraian yang terjadi pada krama istri (WNI) akibat perkawinan campuran dengan WNA tanpa perjanjian perkawinan secara adat selama ini berpengaruh pada kedudukan dan status krama istri tidak dapat diterima secara adat. Oleh karenanya dalam rangka merespon kebutuhan hukum di masyarakat yang bersinergi dengan responsif gender, sebagai langkah alternatif, berupa desain 
kebijakan desa adat terhadap perempuan

Bali yang bercerai dari perkawinan campuran dengan menggunakan perjanjian perkawinan secara adat sebagai dasar dalam menyusun awigawig. Berdasarkan pada temuan permasalahan, hasil analisa kasus, dan identifikasi penyebab timbulnya masalah desain kebijakan urgen untuk dirancang untuk melakukan inovasi dalam rangka penemuan bahan pembaharuan hukum adat Bali dalam bentuk awig-awig yang kemudian mengarah kepada pengembangan hukum adat yang mampu memfasilitasi hak-hak perempuan Bali . Untuk dapat melakukan perubahan dalam awig-awig dapat ditempuh dengan nguwah-nguwahin awig-awig atau merevisi terhadap norma awig yang dinilai sudah tidak relevan. Kebijakan pengembangan usaha terhadap perempuan bali pasca perceraian dari perkawinan campuran bermuatan gender dalam hukum, dengan menerima masukan melalui socio legal research ke desa adat maupun kota tentang pengaturan adat dalam awig terhadap perempuan yang melaksanakan perkawinan campuran.

\section{KERANGKA TEORITIS}

Desain adalah sebuah kegiatan kreatiif yang mencerminkan keanekaan bentuk kualitas, proses, pelayanan dan sistem yang saling berhubungan. Desain merupakan faktor yang membangun kegiatan inovasi pemanusiaan teknologi, dinamika budaya dan perubahan ekonomi. Teori transformasi budaya, ide tentang pentingnya "renesans" atau pencerahan kembali desain yang mendorongnya menjadi bagian pemanusiaan kehidupan. Desain dituntut menjadi wacana budaya baru yang lebih mampu mengangkat harkat kemanusiaan di muka bumi(Sachari, Sunarya, 2016 : 182). Kebijakan diperlukan untuk menjawab problem sosial yang kompleks. Kebijakan menempatkan target group harus menjadikannya tidak hanya sebagai objek, namun dapat sebagai subjek atau pelaku dalam proses perumusan kebijakan. Desa adat memiliki forum pengambilan keputusan yang disebut paruman. Paruman adalah sidang permusyawaratan/pemufakatan desa yang mempunyai kekuasaan tertinggi di dalam desa adat. Desa adat dipimpin oleh Prajuru Desa Adat yang dipilih dan ditetapkan oleh masingmasing krama (orang yang menjadi anggota desa adat). Unsur-unsur Prajuru 
Desa Adat terdiri dari: (1) Bendesa Adat, sebagai pimpinan Prajuru Desa Adat, dipilih dan diangkat oleh Krama Desa Adat; (2) Petajuh adalah wakil Bendesa Adat; (3) Penyarikan adalah juru tulis Bendesa Adat; (4) Kesinoman adalah juru arah; (5) Pemangku adalah yang membidangi urusan upacara agara di pura; dan (6) Pesedahan/Petengen adalah bendahara (Isna, 2007:3). Langkah desa adat dalam menuangkan aspek responsive gender ke dalam awig-awig yang mendasarkan pada inisiatif lokal tersebut apabila dilihat dari perspektif sejarah peran desa adat, dapat dikatakan sebagai sebuah sistem pengelolaan kegiatan dalam masyarakat yang didasarkan pada pengalaman dan pengamatan selama bertahun-tahun terhadap lingkungan masyarakat dan alam sekitarnya. Pada kajian penelitian ini kembali desain kebijakan didesain karena ada permasalahan krama istri yang mengalami perceraian dari perkawinan campuran, penyikapan desa adat dalam memberikan perlindungan terhadap perempuan Bali sangat dibutuhkan untuk mewujudkan keadilan gender. Dalam artikel Basuki (2006), menyebutkan batasan mengenai perkawinan campuran menurut Pasal 57 Undang-Undang Nomor 1 Tahun 1974 tentang Perkawinan, antara warga negara Indonesia (WNI) dan warga negara asing (WNA) tunduk pada hukum yang berlainan. Relevan dijadikan rujukan penelitian menurut pertimbangan usulan penelitian yang diajukan oleh tim peneliti juga menelaah tentang perlindungan hukum desa adat terhadap perempuan Bali yang bercerai dari perkawinan campuran dalam rangka menyusun desain kebijakan adat yang mengadopsi kejelasan kedudukan dan status krama istri di desa adat pra dan pasca perkawinan campuran dilakukan dengan memasukkan alernatif penyelesaian masalah berupa unsur perjanjian perkawinan dimasukan ke dalam awig-awig secara adat. Perselisihan pada pasangan perkawinan campuran beda kewarganegaraan yang mengalami kasus perceraian memerlukan perhatian tata hukum yang digunakan dalam penyelesaian perkara perceraiannya (Witaskara, 2016:9). Peneliti memandang perlu mengakomodasi muatan responsive gender sehingga desa adat dalam memberikan perlindungan terhadap krama istri lebih memandang aspek awig-awig sebagai sebuah instrumen hukum yang merupakan ukuran tingkah laku atau kesamaan sikap (standard of 
conduct), juga berfungsi sebagai suatu rekayasa sosial untuk mengubah masyarakat ke arah lebih sempurna. Dalam rangka penyusunan awig-awig desa adat, selain harus memperhatikan dinamika masyarakat sesuai dengan perkembangan jaman, juga tetap mendasari pada nilai-nilai yang hidup dalam masyarakat. Implementasi awigawig desa adat hendaknya berpedoman pada prinsip hukum yang adil, sehingga awig-awig dapat berlaku secara efektif dalam masyarakat (Sirtha dalam Winarta, 2017 : 12). Awig-Awig desa adat dapat berfungsi sebagai alat merekayasa (social engineering) untuk mengarahkan masyarakat menuju tujuan yang diinginkan dan mengembangkan hukum responsif berbasis gender. Hukum adat bersumber pada hukum Hindu dalam hal ini berlaku teori Receptio in Complexu yang diperkenalkan oleh C.F. Winter dan Salomon Keyzer (1823-1868), kemudian diikuti oleh L.W.C. van den Berg (18451927). Menurut teori ini "orang Islam di Jawa menerima masuknya hukum Islam secara integral, sehingga mengikat masyarakat bersangkutan, dengan kata lain hukum Islam mengikat bagi para penduduk asli yang beraga Islam. Sepanjang tidak dibuktikan lain". Bagi masyarakat adat di Bali, teori ini juga berlaku bagi orang Bali yang mayoritas Hindu, yaitu hukum Hindu mengikat orang-orang yang beragama Hindu, sehingga hukum adat Hindu bersumber pada hukum Hindu (Sadnyini, 2016 : 631).

\section{METODOLOGI}

Analisa pada penelitian ini menggunakan analisa SWOT. SWOT berfungsi untuk mengelompokkan isuisu strategis dalam empat komponen, seperti: kekuatan,kelemahan, peluang, dan tantangan/ancaman. Rencana dan arah pengembangannya menyasar pada penetapan regulasi dalam awig-awig yang memuat perlindungan perempuan Bali pasca perceraian dari perkawinan campuran untuk dapat memperoleh kedudukan dan status mewidesa (menjadi warga desa adat) di desa adat setempat; sebagai upaya meligitimasi konsep desain kebijakan desa adat dan penetapan kebijakan desa adat. Arah pengembangan mengacu pada penetapan regulasi perlindungan perempuan perlu didahului dengan pembuatan draft akademik yang proses penyusunannya turut mengakomodasi komponen lokal dan tidak bertentangan dengan produk regulasi di seluruh level. Tedapatnya 
produk hukum Pasal 57 Undang-Undang No.1 Tahun 1974 tentang Perkawinan, maka dalam penelitian digunakan jenis penelitian hukum normatif (normative legal research) dengan mengkaji peraturan perundang-undang atau bersifat doktrinal (kajian terhadap hukum positif). Sedangkan untuk mengkaji penerapan dari ketentuan yang berlaku menggunakan penelitian hukum empiris dengan kajian terhadap fenomena perkawinan campuran di mana terjadi perceraian, penyikapan adat terhadap krama istri yang kembali ke keluarga bajang (remaja) penting dituangkan dalam sebuah awig-awig dengan cara nguwah-nguwahin awigawig merubah terhadap aturan awig yang belum sesuai dengan cara merevisi, menambahkan, bahkan mengganti apabila tidak sesuai dengan tingkat keberterimaan krama desa adat di provinsi Bali. Populasi adalah seluruh obyek atau seluruh individu atau seluruh gejala/kejadian atau seluruh unit yang diteliti yang terdapat di 5 (lima) kabupaten, diantaranya: Badung, Buleleng, Gianyar, Karangasem, dan Kodya Denpasar. Penggunaan Stratified Random Sampling adalah untuk memperoleh perbandingan antara wilayah desa dan kota dalam kasus perempuan Bali yang mengalami perceraian dari perkawinan campuran. Jumlah sampel dalam penelitian ini yaitu sejumlah 65 orang. Informan yang berkompeten meliputi: (1) Prajuru desa adat Bondalem; (2) Prajuru desa adat yang ada di wilayah kota dari 4 Kabupaten yang tersisa selain kabupaten Buleleng. Sumber data primer, hasil penelitian dengan pihak responden dan narasumber. Data sekunder diperoleh dari sumber dokumen hukum, anatara lain. UU No.1 Tahun 1974 tentang Perkawinan, awig-awig, jurisprudensi, dan sebagainya yang berkaitan dengan pembahasan penelitian. Teknik pengumpulan bahan hukum dilakukan melalui inventarisasi bahan hukum yang relevan dengan penelitian quisioner dan Focus Group Discussion, Bungin (2010) adalah data dukung untuk kritik dan masukan terhadap desain kebijakan desa adat yang menuju ke arah responsif gender.

\section{HASIL DAN PEMBAHASAN}

Merujuk pengaruh hukum Hindu dalam hukum adat di Bali juga melingkupi desain kebijakan desa adat yang memuat perlindungan perempuan setelah perceraian dari perkawinan campuran, di mana tidak terlepas dari ajaran Tri Hita Karana (tiga penyebab 
manusia dapat mencapai kebahagiaan) dengan menjaga keselarasan antara manusia dengan Tuhannya, yaitu dapat diwujudkan dengan krama istri dapat diterima ngayah kembali pada saat piodalan di pura. Peluang atau kesempatan bagi perempuan Bali dalam bidang pengembangan usaha pasca perceraian dari perkawinan campuran, mengedepankan prinsip responsive gender ke dalam awig-awig, ilmplikasi muatan toleransi menyama braya, status krama istri, serta menjalankan kewajiban ngayah pada saat piodalan di pura Tri Kahyangan menjadi tujuan dari muatan gender dalam hukum terhadap usaha yang dikembangkan. Menjaga harmoni dengan sesama, dengan cara mengembangkan sikap menyama braya sebagai bagian yang tidak terpisahkan dalam kehidupan masyarakat untuk menjaga kerukunan, bekerjasama, dan menjaga keharmonisan antar krama desa (warga desa), baik krama istri (warga perempuan) maupun krama lanang (warga laki-laki). Sinergi dengan lingkungan dapat diwujudkan oleh desa adat terhadap krama istri, dengan menerima kembali sebagai krama desa, dan krama istri juga dapat melaksanakan segala ketentuan yang termuat dalam awig-awig. Krama istri beserta para krama desa lainnya secara bersamasama mengkonsepsikan dan mengaktifkan upacara keagaamaan untuk memelihara kesucian desa. Rasa kesatuan sebagai krama desa adat (warga desa adat) terikat oleh karena awig-awig dalam lingkup karang desa (wilayah desa) dan bertalian erat dengan Tri Kahyangan Tiga (tiga pura desa sebagai tempat persembahyangan bagi warga desa adat).

\section{KESIMPULAN}

Kebijakan responsive gender dalam pengembangan usaha sudah diakomodasi oleh awig-awig desa pakraman di beberapa daerah di Provinsi Bali. Kesemuanya berlandaskan pada konsep menyama braya yang masih terpelihara dengan baik, demikian juga halnya ada perjanjian pra nikah yang diakomodasi oleh awig-awig memberikan kesempatan bagi perempuan Bali yang mengalami perceraian diterima kembali oleh desa adat dengan persetujuan melalui dharma pula (keputusan bersama) untuk memberikan pihak perempuan tersebut kesempatan untuk mencari nafkah dan membuka peluang usaha di eilayah desa setempat. 


\section{REFERENSI}

1. NusaBali.com, 17 April 2018.

Tenaga Kerja Asing Didata.

Terbitan 18 April 2018.

2. Sudiana, Ketut, A.A. (2012). Upaya - Upaya Untuk Mengimplementasikan Konvensi Wanita Ke Dalam Awig- Awig Desa Pakraman. https://ojs.unud.ac.id/index/php/ srikandi/article/view/2897/2066.

3. Winarta, E., \& Nyoman. (2017).

Kawin, Hak Pakai atas Rumah

Hunian Warga Negara Asing dalam Perkawinan Campuran Tanpa Perjanjian. Jurnal Ilmiah

Prodi Magister Kenotariatan Acta Comunitas, 42.

4. Sachari, A., \& Sunarya, Y. Y. (2006). . Pengantar Tinjauan Desain. Bandung: ITB.

5. Isna Alizar (2007). Adat Masyarakat Bali dalam Penanggulangan Kemiskinan. Jurnal Studi Islam dan Budaya (Ibda), Volume 1 No.5, Jan-Jun
2007. 141-156. Purwokerto: P3M STAIN Purwokerto.

6. Basuki, Z. J. (2006). Dampak Perkawinan Campuran terhadap Pemeliharaan Anak. Indonesian Journal of International Law, 3(4), 596.

7. Witaskara, A. T. (2016). Pelaksanaan Perceraian Dalam Perkawinan Campuran (Studi Kasus Perceraian Di Pengadilan Negeri Singaraja),6.

8. Sadnyini, I. A. (2016). Implementasi Keputusan MDP Bali Tahun 2010 Ke Dalam Awig-Awig Desa Pakraman Di Bali. Jurrnal Magister Hukum Udayana Jurnal (Udayana Master Law Journal), 5(3), 631.

9. Winter, C.F., Keyze S. (18231868). Policy Analysis: Concepts and Practice. New Jersey : Third Edition, Prentice Hall, New Jersey.

10. Bungin, B. (2010). Metodologi Penelitian Kuantitatif (Edisi Kedu). Jakarta: Prenada Media Group. 